DOI: $10.52950 / E S .2021 .10 .2 .001$

\title{
THE CAUSAL IMPACT OF THE RAPID CZECH INTEREST RATE HIKE ON THE CZECH EXCHANGE RATE ASSESSED BY THE BAYESIAN STRUCTURAL TIME SERIES MODEL
}

\author{
ONDREJ BEDNAR
}

\begin{abstract}
:
I have employed the Bayesian Structural Time Series model to assess the recent interest rate hike by the Czech Central Bank and its causal impact on the Koruna exchange rate. By forecasting exchange rate time series in the absence of the intervention we can subtract the observed values from the prediction and estimate the causal effect. The results show that the impact was little and time limited in one model specification and none in the second version. It implies that the Czech Central Bank possesses the ability to diverge significantly from the Eurozone benchmark interest rate at least in the short term. It also shows that the interest rate hike will not be able to curb global inflation forces on the domestic price level.
\end{abstract}

\section{Keywords:}

monetary policy, exchange rate, optimum currency area

JEL Classification: F39, A10

\section{Authors:}

ONDREJ BEDNAR, Prague University of Economics and Business, Czech Republic, Email: Ondrej.bednar@vse.cz

\section{Citation:}

ONDREJ BEDNAR (2021). The Causal Impact of the Rapid Czech Interest Rate Hike on the Czech Exchange Rate Assessed by the Bayesian Structural Time Series Model. International Journal of Economic Sciences, Vol. X(2), pp. 1-17., 10.52950/ES.2021.10.2.001 


\section{Introduction}

The objective of this paper is to measure the impact of the recent rapid increase of the Czech benchmark interest rate on the Koruna/Euro exchange rate. I consider this topic to be important from two reasons.

This is the special moment in the history of Czech monetary policy when the two-week repo rate was doubled in one move. As far as the Czech Central Bank online records go (back to 1995), this has never happened. This move can reveal something about the monetary policy independence of the Czech Republic and how beneficial or costly the Euro adoption would be. The results show that Czech interest rate changes have a limited impact on the exchange rate. The unexpected rise of the interest rate projected itself onto the currency value, but the effect was very temporary - lasting only about a week. Other strong influences made the Koruna depreciate despite reports on monetary tightening continuation. The fact that the interest rate differential has little effect on the Koruna value can be used as an argument that Czech monetary policy is independent, as it can change its interest rates without immediate effect on the external balance. Losing independent monetary policy is the main cost of joining a currency union and some economists claim that open small economies have limited possibilities to use the tool of interest rates as it has unwanted influence on the country's exchange rate. (Plümper \& Troeger, 2006 or Rey, 2015 and others)

This is also a very hotly debated topic in terms of how the Czech central bank should act in the situation of rapidly surging core and external inflation (Čečrdlová, 2020), especially at the time of post-pandemic recovery. The incumbent Czech prime minister strongly criticizes the central bank board blaming it for the "strangling economy" while other countries also face the same inflation forces and have not yet tightened monetary policy. (Babiš, 2021) On the other hand, the head of the monetary analysis section of the central bank defends the move on the institution's blog as necessary to anchor inflation expectations (Král,2021) and cool down the shooting up property prices (Hromada, 2021 or Kadeřábková, 2020). The analysis shows that the increase of the interest rates in October was not sufficient to significantly appreciate the Koruna and thus limit importing inflation.

I employ rather a new approach to the causal inference popularised by Google's Kay Brodersen's (2015) paper and a tool based on the R' s Bayesian Structural Time Series (BSTS) package. Foreign exchange rate forecasting with a short horizon is notoriously very difficult as some even say that it is a random walk (Rossi, 2013). I attempt to predict counterfactual time series with a posterior probability interval, therefore not an exact price, rather a band to find out what would happen in the absence of the unexpectedly strong hike in the interest rates. The counterfactual series is then compared with the real observed exchange rate. The synthetic control group unaffected by the treatment of increased Czech interest rates is made from other Euro-currency pairs that predict most closely the Czech exchange rate before the intervention. 
The main contribution of this paper is the analysis of the current issue that is crucial in the long undecided debate regarding the adoption of the Euro and the novel application of causal inference to the decision of the monetary authorities.

\section{Literature overview}

I have split the literature review into two parts. The first part is based on theoretical arguments and the second on foreign exchange rate predictions and the Byesian Structural Time Series Model and its empirical use.

\subsection{OCA literature}

One of the main results of the largely influential Mundell-Flemming model is that an economy cannot simultaneously maintain a fixed foreign exchange rate, free capital flow and independent monetary policy. The concept also known as the impossible trinity implies that by forsaking a foreign fixed exchange rate, a country can conduct a fully independent monetary policy (Fleming, 1962; Mundell 1963). The concept is empirically proven by Obstfeld, Shambaugh \& Taylor (2004) who researched a large dataset of interwar period countries. Gold standard countries with free movement of capital follow the base interest rate but non-peg countries do not follow the same base interest rate.

However, later literature showed that such a view is misleading as independent monetary policy is also dependent on the size of the economy or the currency area. Therefore, small open countries have in fact limited monetary policy autonomy under any exchange rate regime. If an open economy experiences an adverse economic shock that motivates the monetary authority to decrease the key interest rate, then ceteris paribus, the measure will have a negative effect on capital inflow to the country. In turn, this will affect the foreign exchange rate. The country's currency will depreciate in relation to other currencies. The more open the economy, the larger the effect of such countercyclical measures on the country's inflation (McKinnon,1963).

Hausmann et al. (2001) finds that interest rates in countries with a floating exchange rate regime respond to the US monetary policy shocks just as the countries with fixed exchange rates do. Also, one of the conclusions of Frankel (1999), who examines a broad range of countries shows that interest rates in Latin American countries are more sensitive to the US monetary policy shocks if the country has a loose Dollar peg rather than a tight Dollar peg. Overall, he does not detect any strong connection between currency regimes and interest rate autonomy.

Calvo \& Reinhard (2002) show that especially in smaller economies that claim to have a floating exchange rate regime, it is very common to use the interest rate as a tool to stabilize external shocks and the country's exchange rate. They call it "fear of floating". Countries with "fear of floating" have limited monetary independence as they utilize an interest rate tool to mitigate external shocks that should theoretically be handled by the shifting of the exchange rate.

A very influential paper by Rey (2015) shows that "cross-border flows and leverage of global institutions transmit monetary conditions globally, even under floating exchange-rate regimes", therefore she dismisses the classical notion of a Trilemma and says that only a Dilemma exists. This means there is only a choice between having unrestricted capital flows or independent monetary policy. She also claims that in a situation of globalized finance, the monetary policies of "key countries" affect other countries' monetary and financial conditions. Financial imbalances can occur, and impact periphery countries' output or due to foreign debt on periphery countries' companies, the so-called balance sheet effects change to the monetary policy impacts on the economy (Rey, 2016). 
Obstfeld (2015) sees a bigger problem for small open economies within the existence of a financial trilemma rather than a monetary trilemma (or dilemma). While he posits himself between two "extremes" in the views on the monetary trilemma - Rey's "trilemma is dilemma" and Woodford's "totally independent" monetary policy under a flexible exchange rate, Obstfeld claims that due to globalization the central bank's decision making became more difficult. This is especially due to the existence of the financial trilemma. The monetary authorities must consider the effect of their monetary moves on the stability of the financial system.

\subsection{Exchange rate predictions literature}

\subsubsection{Classic}

There is a great deal of existing literature on the exchange rate determination. The two classic approaches developed in the 70 s are monetary and portfolio balance approaches.

The monetary approach emphasizes that the relative price of two currencies is determined primarily by the equilibrium of the demand and supply for both money stocks outstanding. The typical and famous concept that belongs to this approach is Purchasing Power Parity (PPP) and Uncovered Interest Parity (UIP) (HODRICK,1978). The portfolio balance approach was developed by Branson (1977). In brief, it claims that UIP does not hold, because domestic and foreign assets are not perfect substitutes.

Barbara Rossi (2013) in her metastudy provides an extensive overview on how to predict exchange rates and why it is so difficult. She comes up with five general conclusions. First, the best predictors are based on Taylor's fundamentals and net foreign asset positions. Second, the best predictive models are linear ones. Third, data transformations may impair the models' predictive abilities. Fourth, empirical results vary with the sample period, forecast horizon and forecast evaluation method. Models based on Taylor's rules have the best predictive capability at short time horizons.

All these models are based on variables that are at best available monthly (inflation). Other variables such as output differentials, output gap differentials or net foreign assets are reported quarterly. However, in this paper I am attempting to forecast the exchange rate in a one-month horizon. The method I use therefore cannot be based on changing fundamentals as they are reported with very low frequency, but to assess the immediate impact on the exchange rate it should be based on the exchange rate time series and other exogenous variables.

\subsubsection{Causal Impact}

The model that I use in this paper is based on Brodersen (2015) and Varian \& Scott (2015). BSTS models have several advantages over standard frequentist state and space models such as ARIMA. The BSTS model can utilize large amount of regressors and let the parameters change over time.

Feroze (2020) used the model to assess the dynamics of COVID 19 and analysed the causal impact of lockdowns in different countries on the spreading of the virus. He shows that the model produces more accurate results than ARIMA models.

Takyi \& Bentum-Ennin (2021) examine the impact of COVID 19 on 13 African Stock markets. They show that 10 countries' stock markets were significantly adversely affected by the epidemic, while the remaining three countries were not significantly affected. 
Booking.com, a Dutch company that functions as an online travel agency claims to use the model to evaluate experiments that they cannot or do not want to randomize, such as a marketing campaign where for various reasons they cannot randomize the audience. They claim that to validate the tool based on the model, they measure the effect of a randomised experiment and compare it with the results of $A / B$ testing. The results were almost identical to the estimates of the (randomized) A/B testing. (Katsimerou, 2021)

Pinilla et. al. (2018) use the BSTS model to investigate the effects of a partial and total ban of public smoking on sales of cigarettes. They conclude that a partial ban on public smoking did not affect cigarettes sales, while a total ban did.

\subsubsection{Machine learning approaches}

Among recent research in forex forecasting there are a large volume of papers that use machine learning approaches to the forecasting of exchange rates. The most common algorithms used are either neural networks or deep learning and their many variations. The machine learning models are often used for automated trading (Islam et. al.,2013), (Sezer et.al., 2020), (Oancea \& Ştefan, 2014).

\section{Argument}

I would like to contribute to the discussion on the effectivity of the Czech monetary policy. The goal of the paper is to assess how much a change in the benchmark interest rate immediately impacts the exchange rate. It would be normally quite difficult to do as one could argue that the markets already accounted for the expected change in the interest rate. Czech central bank often signals its steps in advance and the changes in the interest rates upwards are usually only by $0.25 \%$ at a time. The perfect opportunity presented itself on 30.9.2021 when the Czech central bank hiked the two-week repo rate by $0.75 \%$ which was widely unexpected. ${ }^{1}$

Why should we be interested in the strength relation between the Czech interest rate and the EURCZK exchange rate? There is a theoretical (long-term) reason and a practical (short-term) reason.

The former one comes from Optimum Currency Area Theory which states that a cost to a country joining a currency union is losing its monetary policy independence. But what is the monetary independence? An elegant definition is provided in Obstfeld et. al (2004): independent monetary policy is "the ability of the central bank to set interest rates independently of international rates". Some economists claim that interest rate should only be used to impact the shocks within the economy, while floating exchange rate should accommodate external ones. (Goczek \& Mycielska 2013) McKinnon already in 1963 wrote about small countries' diminished capability of using interest rates to affect business cycle due to the movement of international capital. More recently, Helene Rey (2015) shows that due to the unrestricted capital flow, small countries must adjust their interest rates to the conditions created by major currencies. All these arguments rely on the strong link between interest rate differential and small economy' $s$ exchange rate. If the arguments are right, such a spike in interest rate, as on the last day of September 2021, should cause appreciation of the Czech currency.

The practical reason is to have another piece of information to assess whether the central bank decision was right. Statement of the bank board explaining the CB' s move says: "The current

\footnotetext{
${ }^{1}$ Most of the Cezch analytical outlets expected maximum hike of 0.5\%. See Gurstler,2021 or Csas.cz., 2021. or Fxstreet.Cz. 2021.
} 
outlook for foreign industrial producer price inflation has been revised markedly upwards, especially for the near future. This is due to persisting disruptions to material and component supplies and high global demand for the production of the industrial sector. Along with rising prices of electricity and gas on commodity exchanges, this will also lead to an increase in the outlook for consumer price inflation this year and the next.". It also says that the core inflation is caused by growth in the cost of owner-occupied housing and rising prices in the reopened services sector. Goods and food prices' surge contribute as well. (ČNB, 2021) There is a very significant part of the inflation that is imported. The inflation is caused by short-term negative supply shock. If the inflation stems only from overheating aggregate demand the textbook response is to raise interest rates. (Moenjak, 2014) However, negative external supply shock results in diminished economic activity and higher prices. Increasing interest rates may have two immediate impacts on economy. These are change in the inflation expectations and possible exchange rate shift. The transmission effect to real economy in the Czech Republic is lagged by about 1 year. (Havranek \& Rusnak, 2012). The central bank also admits its monetary policy horizon is in 1 year and according to their own prediction the inflation will already be within the tolerance band when this move will finally materialize (see in Figure 1). Therefore, I argue that the CB's objective of the sudden increase in interest rate was to strengthen the Koruna.

Figure 1: Czech inflation rate, past and prediction 30.9.2021

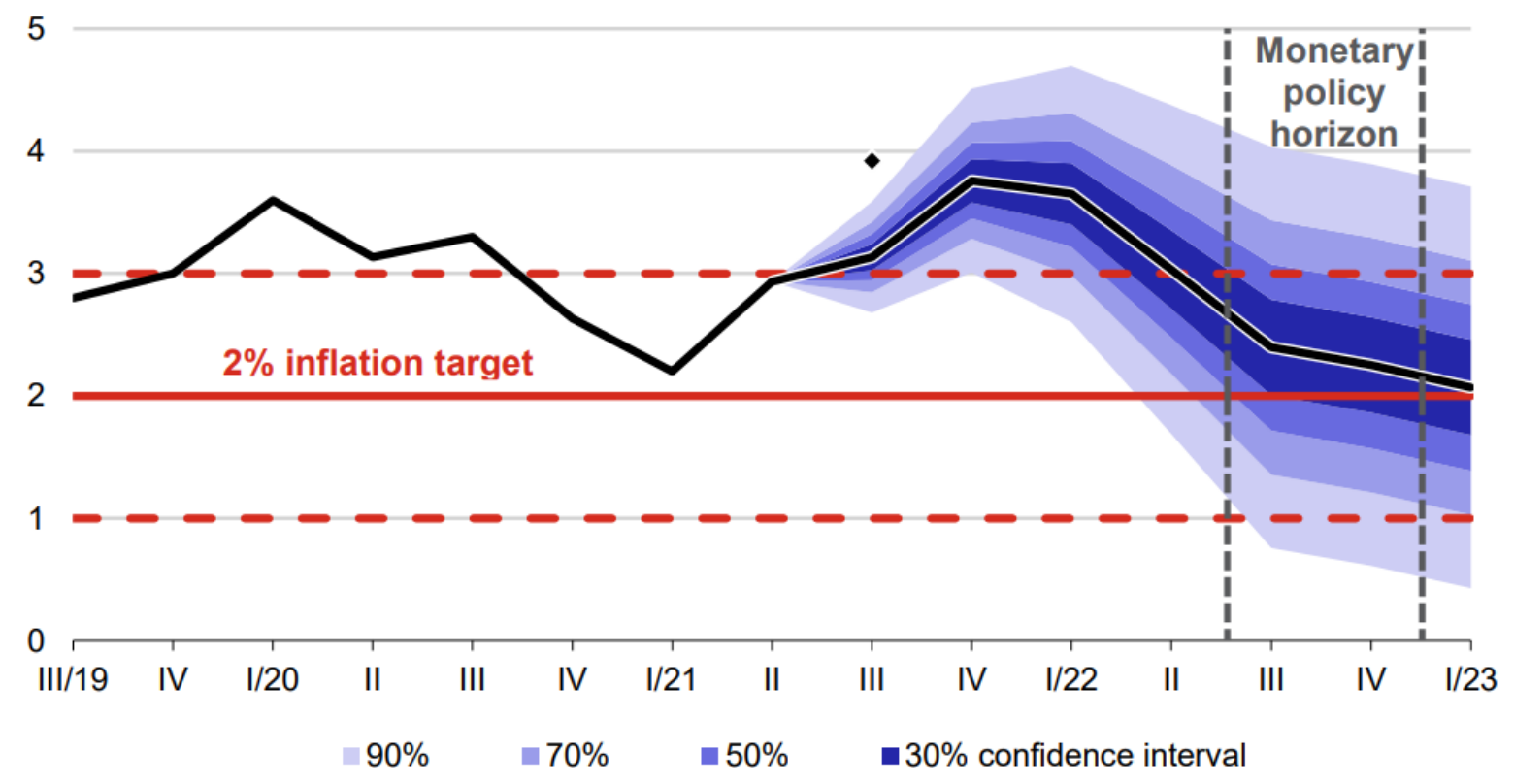

Note: $y-0-y$ changes in \%.

Source: CNB Board decisions statement

In conclusion, the theoretical view says that to have proper functioning monetary policy, there should be little connection between interest rate and exchange rate. On the other hand, the Czech CB tries to exploit this potential connection.

This paper aims to analyse whether the increase in interest rate had the intended effect by CB and provide information on the strength of the link between interest rate and exchange rate. 


\subsection{Method}

The best way to assess the causal impact of change in a country's main interest rate on its currency exchange rate would of course be with a Randomized Controlled Trial (RCT). Unfortunately, this is impossible in most cases of macroeconomics including ours. We cannot have multiple Czech Republics to which we randomly assign a hike in the interest rate. Therefore, we need to utilise other ways to handle the problem. So called quasi experimental methods (QEM) are often used in such cases. These are generally considered less robust than the RCT. One of the strongest types of quasi experimental methods that is particularly used is the interrupted time series (ITS) (Hudson et al. 2019).

The ITS method involves tracking the pre-intervention data and the post intervention data. The principle lies in construing counterfactual data for the post period. That is, we predict what would have happened, had the intervention not taken place. There are several methods to predicting the counterfactual series. The most common one is a structural time series where the time series is compiled from different components such as trend, periodicity, sudden spikes and so forth. The most common representative of a structural time series is the ARIMA model and its derivatives. Another, perhaps less popular, is the Bayesian time series, which is used in combination with the synthetic controlled method in this paper. The other method to predict counterfactual series is General Additive Models. This approach attempts to approximate the time series as a combination of functions.

Difference in differences (DID) is a broadly used QEM of causal inference which had already originated in the 19th century. In short, the DID 'compares the difference in outcomes after and before the intervention for groups affected by it to this difference for unaffected groups' (Bertrand et.al, 2004)

Abadie \& Gardezabal (2003) initiated improvement of DID by constructing a synthetic control group that attempts to imitate the treated series. The idea is that a combination of different control units is better than any single control unit. In crude words, by combining different control patients with different features, we should be able to construct more similar patients to the treated one than any single control patient.

\subsection{Causal Impact}

A powerful tool called Causal Impact which combines the above-mentioned Bayesian time series and synthetic control methods was published by Brodersen et. al. (2015) from Google. There are three sources of information to construct the synthetic control. The pre-intervention time series behaviour is the first one. The second one is the behaviour of other time series that were predictive of the treatment series before the intervention. Based on their relationship to the treatment time series pre-intervention, we can establish how the treatment series would behave counterfactually. The third piece of information for computing the counterfactual is the prior knowledge about model parameters. The three sources of information are combined into a state-space time series model. One part of state is a linear regression on the concurrent regressors. The model can select from a large set of potential controls by using spike-and-slab priors on the set of regression coefficients. The posterior distribution of the counterfactual series is estimated given the pre-intervention treatment series and post-intervention control series. The difference between the prediction and observed response makes the semiparametric Bayesian posterior distribution for the causal effect.

The model used here is following the exact specification by Brodersen et. al. (2015), hence I will not repeat it here. 
The model is implemented in $\mathrm{R}$ and Python; the packages for $\mathrm{R}$ and Python are called Causallmpact. However, they do differ in the use of algorithms for posterior inference. The $\mathrm{R}$ package uses the Markov Chain Monte Carlo (MCMC) and Python uses the Kalman filter. I used the $R$ version in this paper.

\subsection{Data}

The whole analysis is conducted on the exchange rate of currency pairs where the dependent variable is EUR/CZK and independent variables (regressors) are other Euro currency pairs. ${ }^{2}$ The exchange rates used are daily averages. The source of the data is Eurostat. Information on the monetary intervention is sourced from websites of the Czech National Bank.

\subsection{Assumptions}

Like with all QEMs, one needs to make strong assumptions to infer valid conclusions. Unlike in DID we do not need to assume that the regressors (control group) follow the same trend. This is thanks to the use of synthetic controls.

\subsubsection{Covariates must not be affected by the intervention}

To some extent every intervention will have an impact on the forex markets. I assume that increasing Czech interest rates in such a fashion has no impact on other currency pairs. The Czech economy and its currency are relatively small. To assure that the assumption is valid, I ran DID regressions on the impact of the CNB intervention on HUF (see Figure 2) and PLN (see Figure 3). If any countries are to be affected by the intervention, I would suspect these based on the relative amount of trade, size of GDP and geographical proximity. The coefficients of the interaction regressor that shows the impact of the treatment on the currency was in both cases statistically insignificant.

Figure 2: DID regression to check for potential spill over effect of the Czech interest rate hike on Hungarian Forint

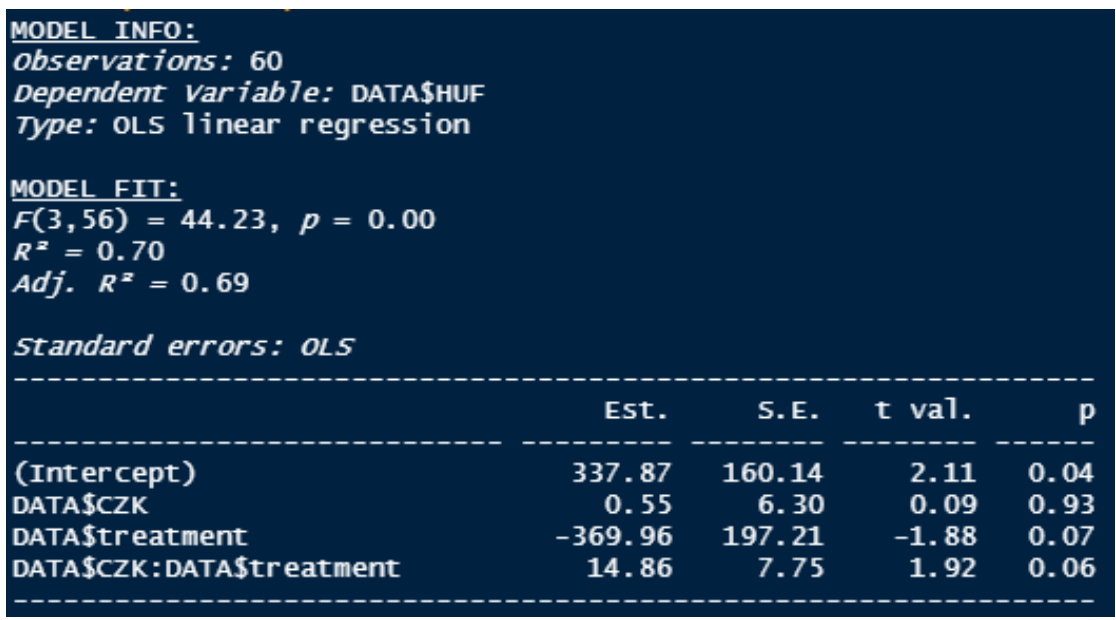

Source: Author

2 The list of all potential regressors is in the appendix 
Figure 3: DID regression to check for potential spill over effect of the Czech interest rate hike on Polish Zloty

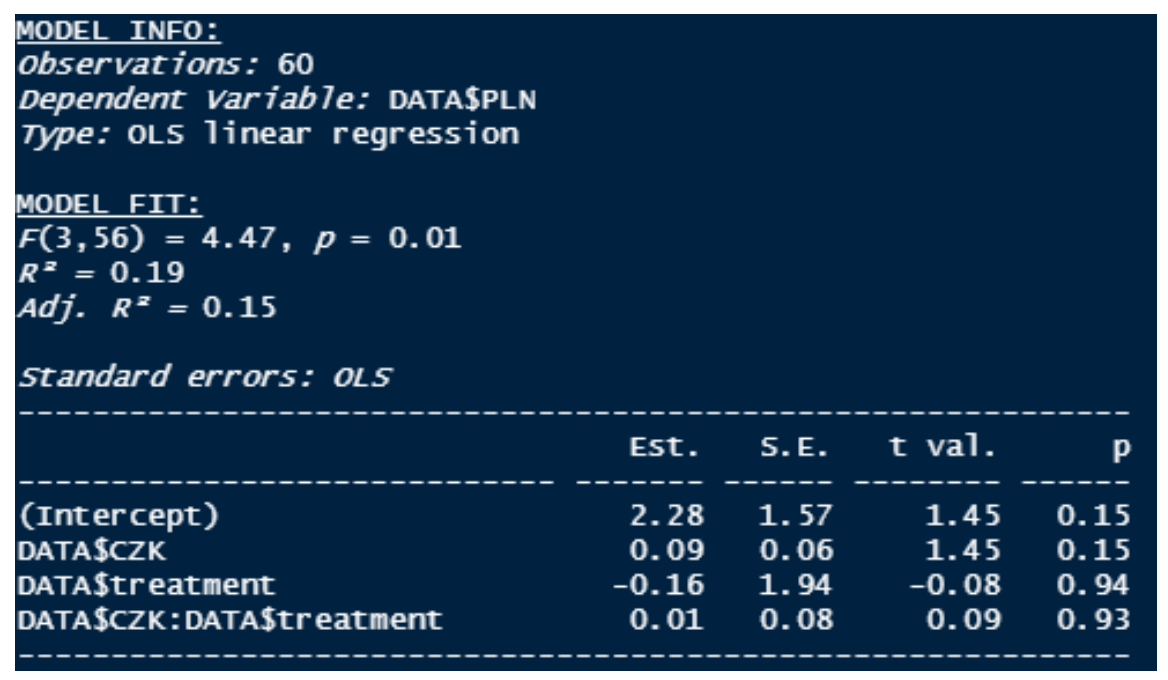

Source: Author

\subsubsection{Relationship between independent and dependent variables remains the same after the treatment.}

The authors of the tool recommend testing the predicting capability of the model on an imaginary intervention. I tried out several such imaginary interventions in the period between the setting of the minimal interest rate benchmark by CNB, that is 11.5 .2020 , and the real intervention, which happened on 1.11.2021. Unless the prediction is longer than a month, the predictions did not significantly differ from observed values.

The Czech Koruna (CZK) is a free-floating currency, and the Czech economy is numbered among the uppermost open economies. ${ }^{3}$ World events have significant impact on the currency and therefore it faces similar external influences as other currencies.

\subsubsection{Specifications of the model}

For each of the two models, I used the common specifications of 10,000 Marcov Chain Monte Carlo samples drawn. All the data were standardized. Prior standard deviation was set to 0.05 . No seasonality component was involved. The alpha of the model is always set to 0.05 ; this means we are looking into a $95 \%$ statistical significancy level.

\footnotetext{
${ }^{3}$ Source: data.worldbank.org
} 


\section{Analysis}

The argument presented in the previous sections implies that the interest rate might influence the Koruna exchange rate. Since the unexpectedly strong hike in the interest rate was announced on 30.9.2021, the model was trained on the data up to that date. Most predictive currency pairs are selected based on the behaviour in the training (pre-intervention) period. The model predicts the counterfactual time series of the EUR/CZK exchange rate from 1.10.2021 in the absence of the intervention. This counterfactual series is compared to the observed series of the EUR/CZK exchange rate. I also predicted the 95\% interval; in the graphs it is the blue band around the forecast.

\subsection{Where to start the pre-intervention time series}

As argued before, the market did not expect the large increase in the interest rate and therefore the ER before the intervention did not involve the increase, as it probably did in the previous hikes. The increase has been the largest one since 1997 in absolute terms and in relative terms (double) the largest recorded. ${ }^{4}$

When selecting the training period, I considered the assumption that the relationship between regressors and response variable must not change. The longer the training period, the higher the risk of breaking the assumption. So, there is a trade-off between having ample data to train on and breaching the assumption.

The short utilized training period starts with the latest previous interest rate change. The Czech Central Bank board decided to increase the two-week repo rate by 25 basis points to $0.75 \%$ on 5.8.2021.

The long training period starts on 7.5.2020 when the Czech Central Bank lowered the two-week repo to its lowest point, which is $0.25 \%$.

\subsection{Results}

The model trained on the period since the last CNB intervention is shown in Figure 1. We can see that after the interest rate hike, the Koruna appreciated and diverged from forecasted counterfactual series. It lasted only about a week until the currency returned to its predicted value. For around half of October, the Koruna started to depreciate and drift away from the forecast. The effect of the intervention only lasted about a week. According to forex analysts, the underwhelming GDP growth, pessimistic Eurozone Purchasing Managers' index (PMI), and the global inflation that appreciates the USD confounded the weakness of Koruna at the end of the October.

Figure 5: Real intervention; The training period is from 6.8.2021. Time is on the $x$ axis. The upper graph shows the model prediction (dashed blue line) of the EUR/CZK exchange rate and its observed values (full black line). The bottom graph shows deviation of the observed values from the forecast.

\footnotetext{
${ }^{4}$ List of rate changes is available here: https://www.cnb.cz/en/monetary-policy/instruments/
} 


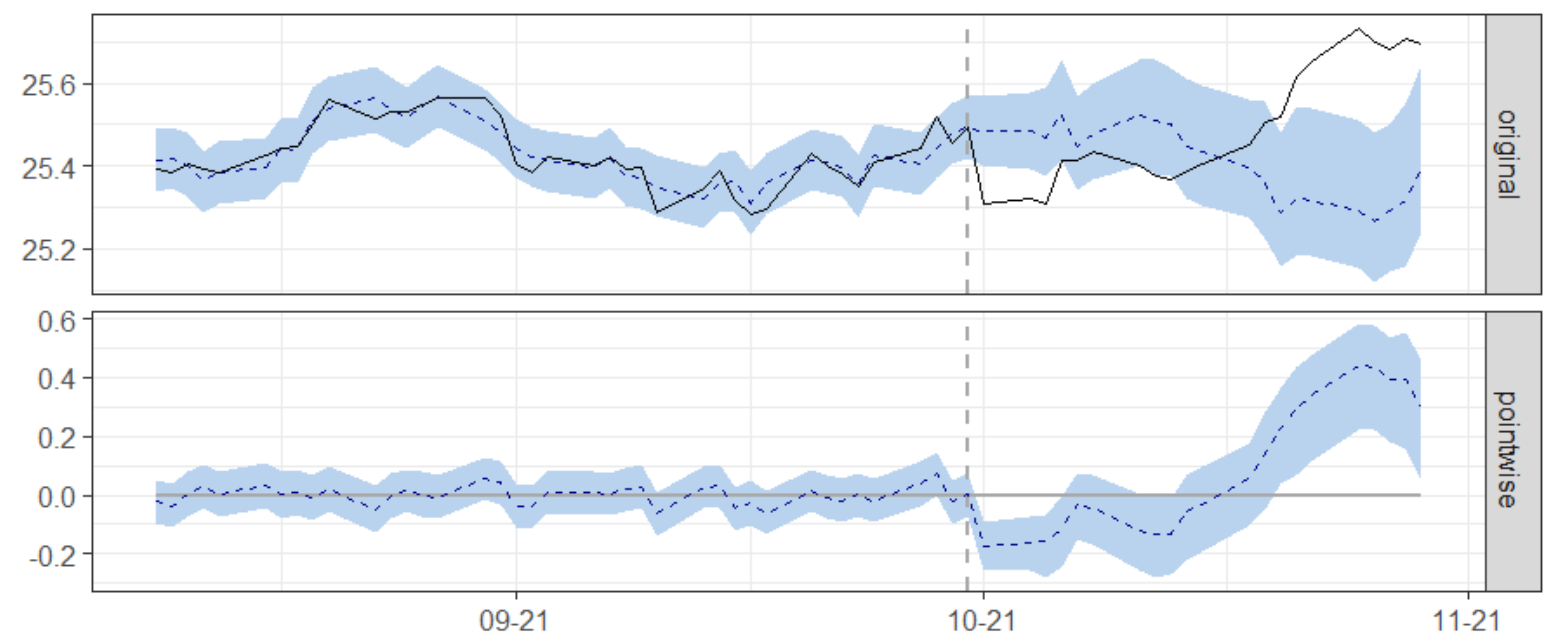

Source: Author

To check how well the data can be predicted before the beginning of the intervention, I ran the model on the previous CNB interest rate increase by 25 basis points on 5.8.2021. I do not expect a strong effect on the exchange rate as this move was announced and widely anticipated. (ČTK, 2021) The results show observed and forecasted series to follow the same trend, but the observed exchange rate had an average value of 25.49. By contrast in the absence of the intervention, the model predicts the average value of 25.60 . The $95 \%$ interval of this counterfactual prediction is [25.48, 25.74]. It appears as though the small change in interest rate caused a slight appreciation on the brink of statistical significance. The counterfactual and observed data are reasonably close enough for me to conclude that the model can predict the data well.

Figure 6: Testing the model on the previous interest rate rise. The training period is from 25.6.2021. Time is on the $x$ axis. The upper graph shows the model prediction (dashed blue line) of the EUR/CZK exchange rate and its observed values (full black line). The bottom graph shows deviation of the observed values.

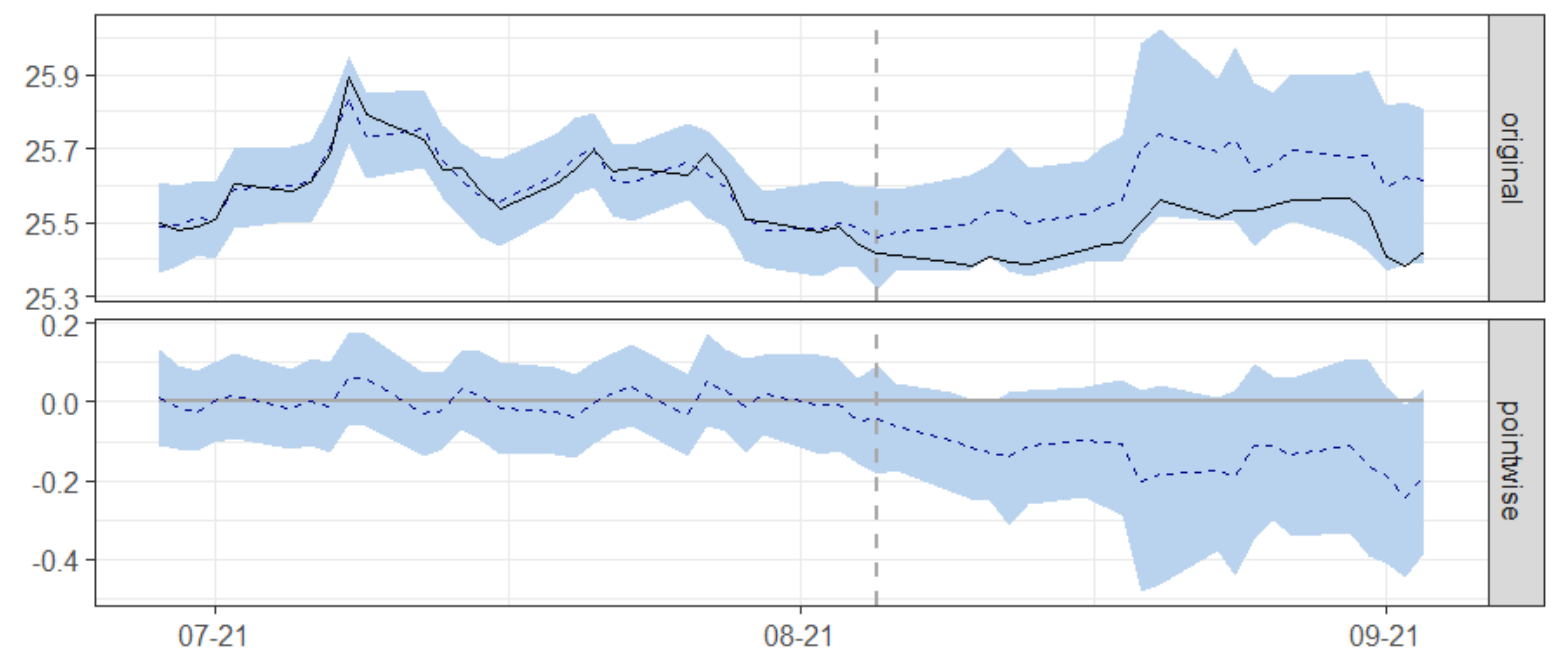

Source: Author 
In the post-intervention period, the observed average exchange rate was 25.50 . In the absence of the intervention, the model predicted an average response of 25.33 with a wider interval than the prediction based on the short training period. The CB move' $s$ effect is statistically insignificant on the $95 \%$ level.

Figure 7: Real intervention; The training period is from 25.5.2020. Time is on the $x$ axis. The upper graph shows the model prediction (dashed blue line) of the EUR/CZK exchange rate and its observed values (full black line). The bottom graph shows deviation of the observed values from the forecast.

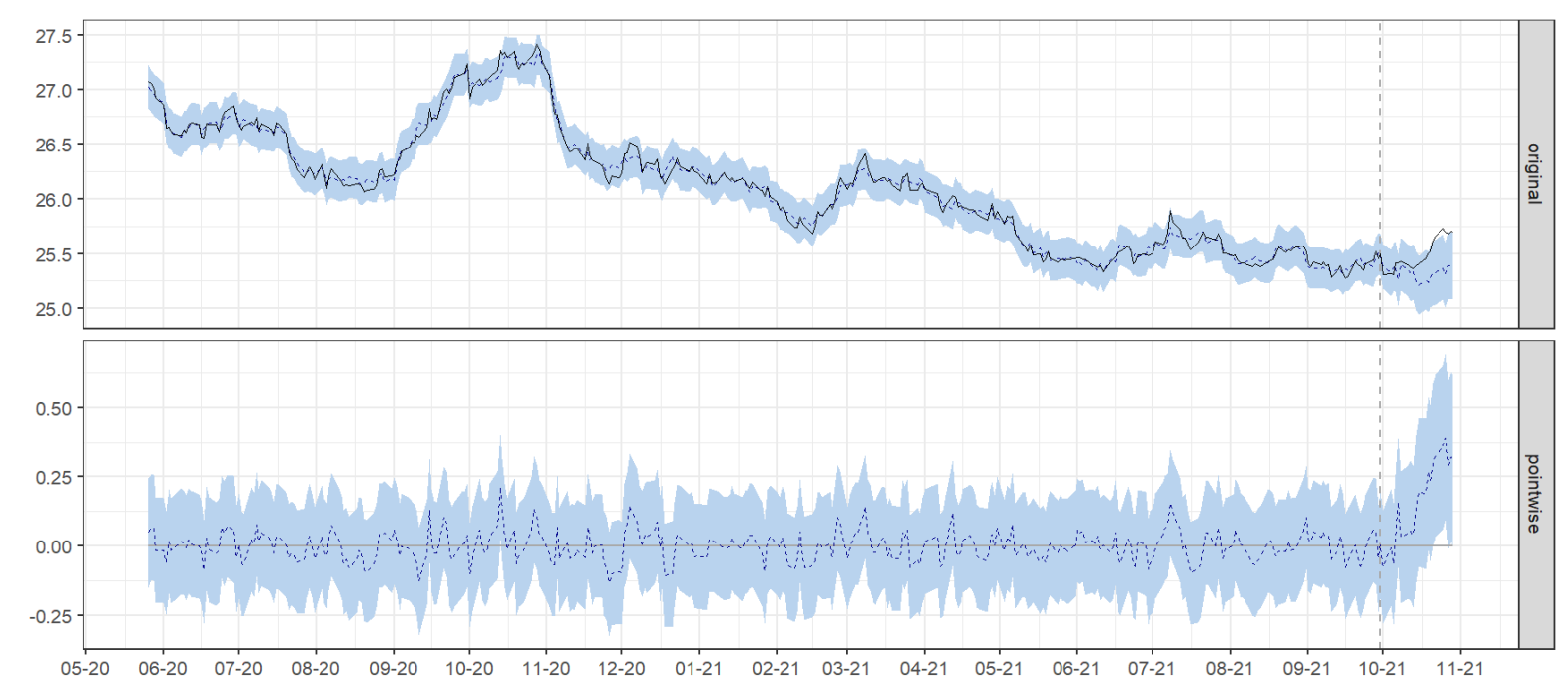

Source: Author

Figure 8: Real intervention; The training period is from 25.5.2020. This is the same model as in Figure 7. The graph only shows a shorter time span. Time is on the $x$ axis. The upper graph shows the model prediction (dashed blue line) of the EUR/CZK exchange rate and its observed values (full black line). The bottom graph shows deviation of the observed values from the forecast. 

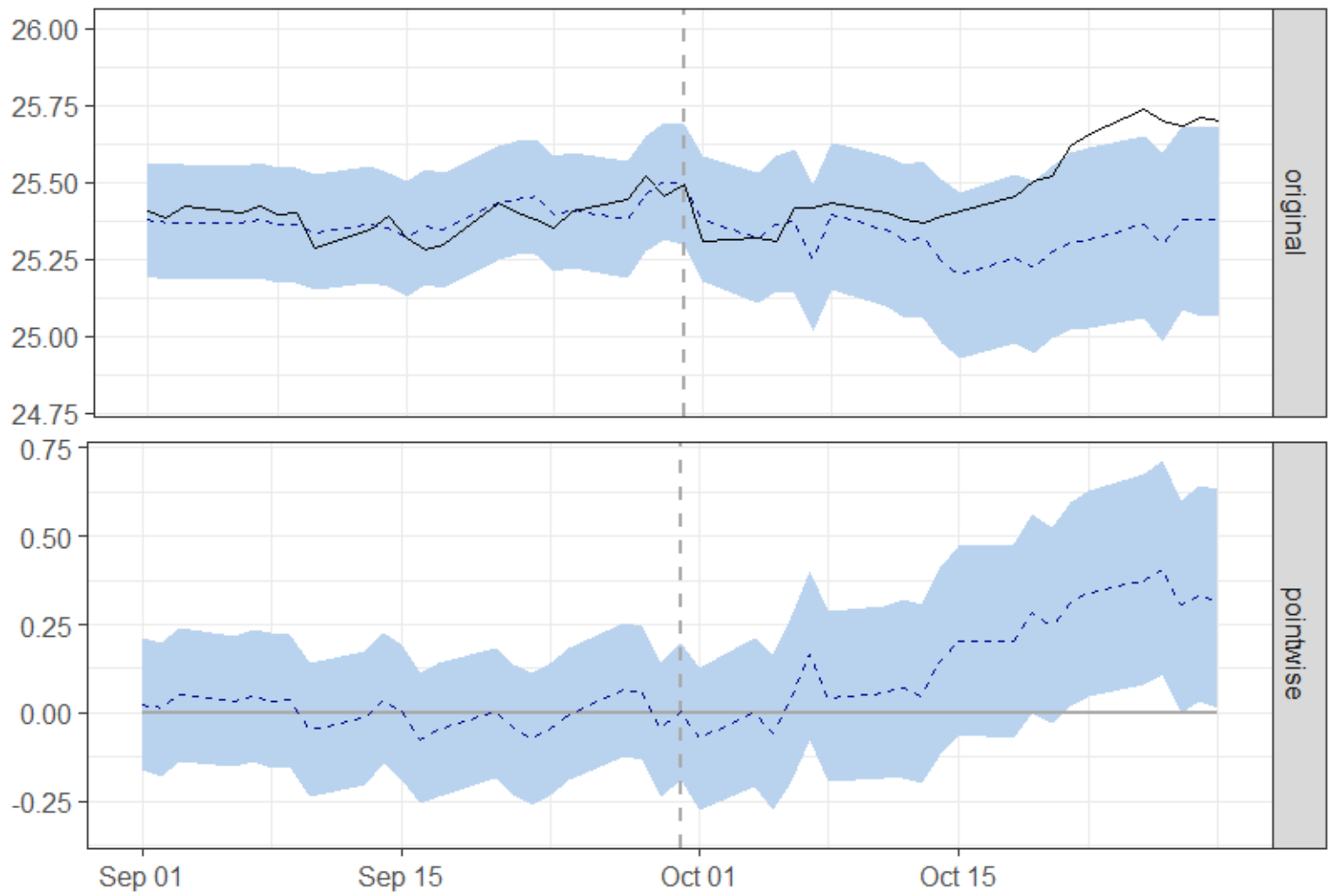

Source: Author

The next two predictions are based on imaginary intervention. This is done to check how reliably the model forecasts the exchange rate moves.

Figure 9: Imaginary intervention. Testing how the model predicts. The observed values should not deviate from the forecasted time series. The training period is from 25.8.2020 The imaginary intervention is on 29.1.2021. Time is on the $x$ axis. The upper graph shows the model prediction (dashed blue line) of the EUR/CZK exchange rate and its observed values (full black line). The bottom graph shows deviation of the observed values from the forecast.

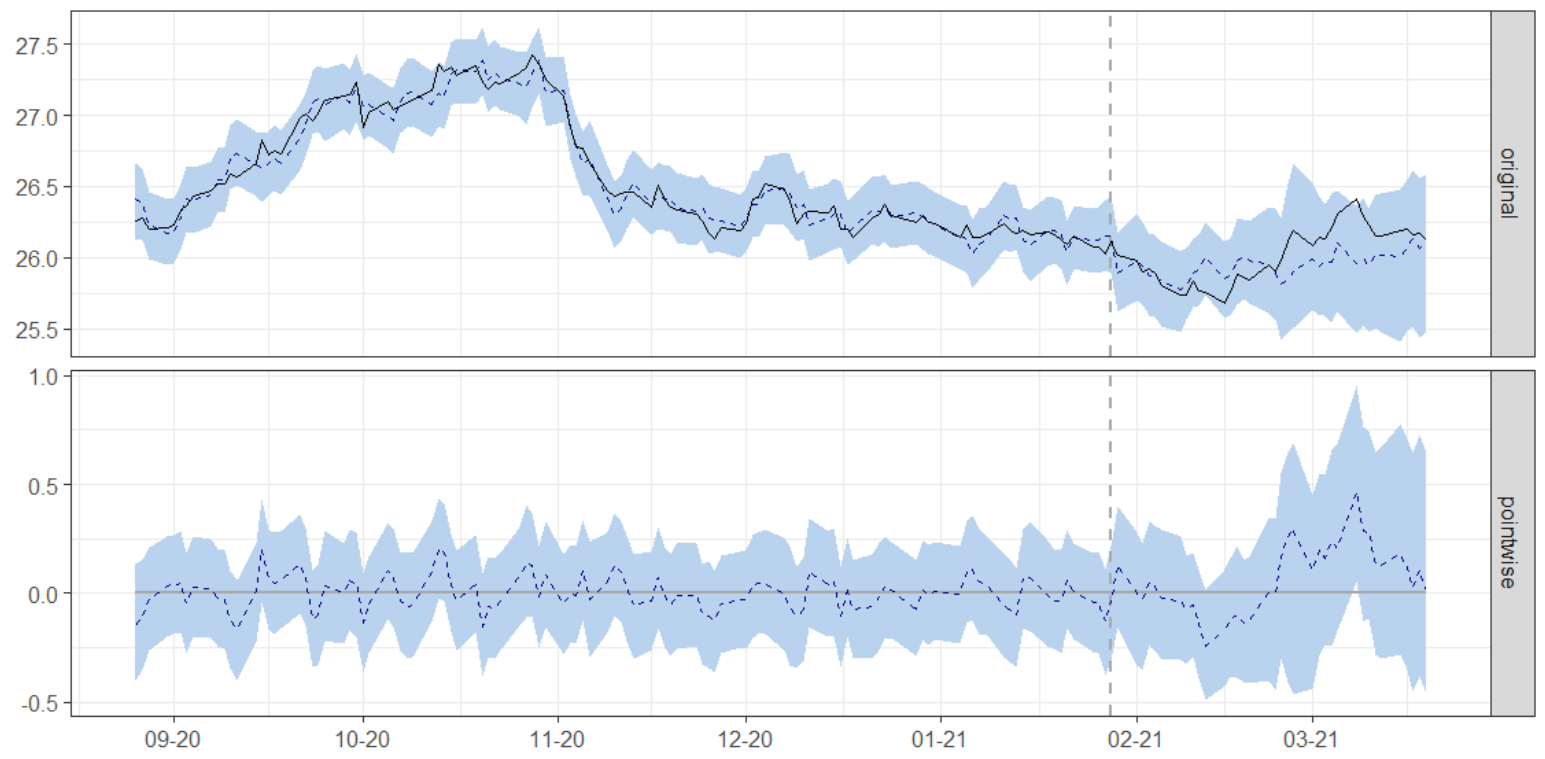

Source: Author 
Figure 10: Imaginary intervention. Testing how the model predicts. The observed values should not deviate from the forecasted time series. The training period is from 25.5.2020 The imaginary intervention is on 25.5.2021. Time is on the $x$ axis. The upper graph shows the model prediction (dashed blue line) of the EUR/CZK exchange rate and its observed values (full black line). The bottom graph shows deviation of the observed values from the forecast.

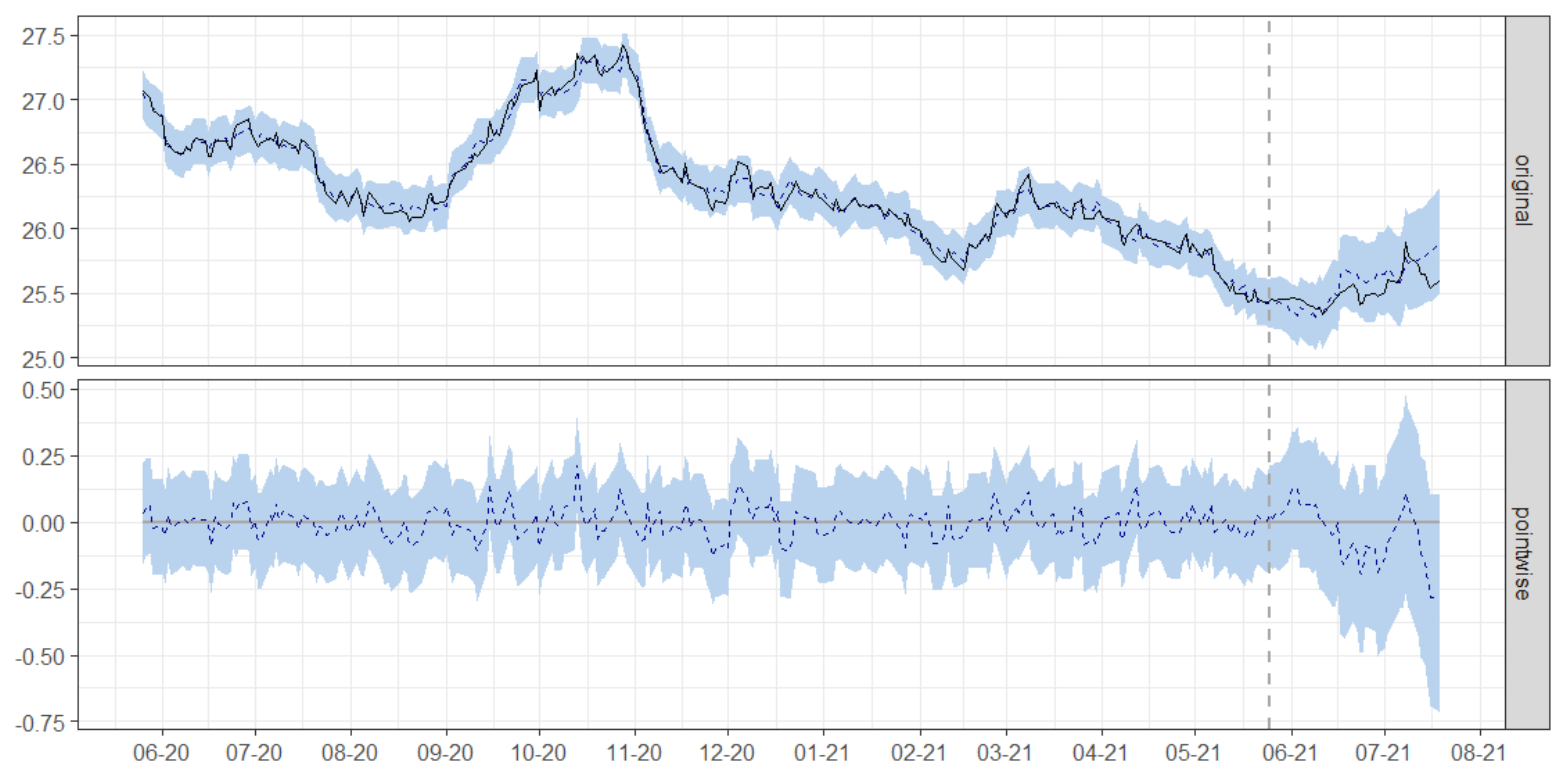

\subsection{Interpretation}

The results show that in the short period version of the model, the currency moved in the desired direction by the CNB and remained there for a week. The one-week move was statistically significant but afterwards the currency slides back to the forecasted values and at the end of the month depreciated even more.

When the forecast involved a longer training period, the significance interval widened, and the one-week appreciation could not even be considered statistically significant (95\%).

If the CB had intended to limit the imminent inflation through the move, which I argue, it did not work out. It appears that at least in the short-term, there are stronger forces in the forex market than interest rate changes by the Central Bank. Maybe, the interest rate hikes might influence in a limited way the exchange rate during period of lull on the markets. This can be seen in Figure 2, which shows the previous interest rate hike that was smaller and expected by the market. However, the overall conclusion is such that the impact of interest rate change on currency value is very low in the short-term.

It provides some evidence to the two arguments of why we should care about the link between interest rates and exchange rate.

As explained in the argument section, according to the OCA theory, the Czech Republic' $s$ interest rate should not be strongly linked with its exchange rate to be able to exercise independent monetary policy. This analysis shows that Czech Republic can shift its interest rates and does not need to immediately worry too much about what happens to the exchange rate. It can use the interest rate as a tool to impact the shocks within the economy. This could be used as a reason to keep the Czech Koruna instead of joining the Euro. The loss of the ability to independently set our interest rate is a certain cost. 
Looking at the correctness of the move in terms of Central Bank goals, the analysis shows that this move will certainly not impact the inflation that is being imported from the global markets. It might change the expectations of the economy's subjects but since the Koruna did not appreciate significantly and for a longer period, the prices of global commodities and products will inflate the economy (Čermáková 2021). Once the move transmits into the real economy, which is approximately in one year, the domestic aggregate demand will be cooled down. This will certainly negatively affect the government budget as the cost of the debt will be higher and incomes due to lower aggregate product will be lower. Apparently, the central bank did not only aim to reduce inflation caused by external phenomenon. It also intended to dampen the domestic overheated real estate market. In my opinion, this move to impact the overheated Czech aggregated demand and sky-high real estate prices is justifiable, yet not perfect, as it does not urgently sort the current inflation and puts the economy in a more difficult position to finally overcome the disastrous Covid slump.

At the time of finishing this article, the Czech National Bank raised the two-week repo rate by $1.25 \%$ citing mostly strong aggregate demand in trading partner countries coupled with disrupted aggregate supply and high commodity prices. ${ }^{5}$ This only confirms the argument that the interest rate hike was due to global inflation and that the CB must aim to appreciate the Koruna. The move makes prospects of economic recovery more complicated. Also, with such a large interest rate differential with Czech main trading partners (Eurozone), it will likely lead to increased Euroization of the Czech economy. That is that Czech economic subjects will more often take loans in the Euro than in the Czech Koruna. This effect is harmful to the independence of the Koruna. If the Czech Central Bank ever wanted to devalue the Koruna, it will have to count on the very negative impact on the Czech Euro debtors, for whom it will increase the relative amount of debt and instalments. The irony is that the Czech Central Bank uses its tools in such a way that might lead to their loss.

This brings me to an obvious question. Would it not be better to use another monetary policy tool to fight international inflation? Why not to sell some of the ample foreign reserves to help the currency appreciate?

\section{Conclusion}

The goal of the paper was to investigate the 'once upon time' opportunity of rapid hike in Czech interest rates and its affect on the Koruna exchange rate. I set forth two reasons why economists should be interested in it.

The method used was a novel Bayesian Structural Time Series, where all Euro-currency (apart from the EUR/CZK) pairs were used as the potential regressors. The counterfactual EUR/CZK time series was predicted and compared to the observed values. Depending on the specification of the model the impact of the interest rate hike was either significant, yet small and time limited or insignificant at all.

Firstly, the Czech Republic goes through lengthy discussion about the Euro adoption and its costs and benefits. The optimum currency area theory states that the main cost of joining a currency union is to lose self-determined monetary policy. However, as proved by Aboiglu (2021), small open economies might have reduced capability of setting interest rates significantly different than large currency blog in the neighbourhood for it might adversely affect the country' s exchange rate. The results show that the short-term link between Czech interest rates and Czech exchange rate is not as strong. Therefore, the Czech central bank may use

\footnotetext{
5 The statement is available at: https://www.cnb.cz/en/monetary-policy/bank-board-decisions/CNB-Boarddecisions-1636040880000/?tab=statement
} 
the interest rate as a tool independent from external forces and it would be a cost if the country joined the Eurozone.

Secondly, the Czech central bank raised the interest rates to curb inflation. They claim that the hike is here to anchor inflation expectation, cool down overheated aggregate demand and limit the import of inflation due to global negative supply shock. The results show that to limit the impact of global inflation the hike was not enough.

\section{Acknowledgements}

This research was founded by grant number IP 500040.

\section{References}

ABADIE, A. AND GARDEAZABAL, J., 2003. The economic costs of conflict: A case study of the Basque Country. American economic review, 93(1), pp.113-132.

ABIOGLU, V., HASANOV, M. (2021). Empirical Investigation of Long Run PPP Hypothesis: The Case of Temporary Structural Break and Asymmetric Adjustment. International Journal of Economic Sciences, Vol. X(1), pp. 1-19. , DOI: 10.52950/ES.2021.10.1.001

BABIS, A., 2021. Operace se vydarila, pacient zemrel. CNB se uplne utrhla ze retezu | Nazory | Lidovky.cz. [online] Lidovky.cz. Available at: <https://www.lidovky.cz/nazory/operace-se-vydarilapacient-zemrel-cnb-se-utrhla-ze-retezu.A211108_195255_In_nazory_Iros> [Accessed 14 November 2021].

BERTRAND, M., DUFLO, E. AND MULLAINATHAN, S., 2004. How much should we trust differencesin-differences estimates?. The Quarterly journal of economics, 119(1), pp.249-275.

BRODERSEN, K.H., GALLUSSER, F., KOEHLER, J., REMY, N. AND SCOTT, S.L., 2015. Inferring causal impact using Bayesian structural time-series models. The Annals of Applied Statistics, 9(1), pp.247-274.

ČEČRDLOVÁ, A. (2020). Symmetric Behaviour to Fulfil the Main Objective as the Basis for the Credibility of Central Banks Behaviour on the Example of CNB . International Journal of Economic Sciences, Vol. IX(1), pp. 68-82. , DOI: 10.52950/ES.2020.9.1.004

ČERMÁKOVÁ K., FILHO, EAH. Effects of Expansionary Monetary Policy on Agricultural Commodities Market. Sustainability. 2021; 13(16):9317. https://doi.org/10.3390/su13169317

ČESKÁ NÁRODNÍ BANKA, 2021. Statement of the Bank Board for the press conference following the monetary policy meeting. [online] Available at: <https://www.cnb.cz/en/monetary-policy/bankboard-decisions/CNB-Board-decisions-1633013280000/?tab=statement> [Accessed 14 November 2021].

CSAS.CZ. 2021. Ranní restart: připraveni na překvápko?. [online] Available at: <https://www.csas.cz/cs/research/analyza/cz/SR244274> [Accessed 14 November 2021].

ČTK, 2021. Koruna dnes stagnovala k euru, vůči dolaru smazala pondělní zisky. [online] Available at: $<$ https://www.ceskenoviny.cz/zpravy/koruna-dnes-stagnovala-k-euru-vuci-dolaru-smazalapondelni-zisky/2072554> [Accessed 14 November 2021].

FEROZE, N., 2020. Forecasting the patterns of COVID-19 and causal impacts of lockdown in top five affected countries using Bayesian Structural Time Series Models. Chaos, Solitons \& Fractals, 140, p.110196.

FXSTREET.CZ. 2021. Forex: Koruna oslabila do blízkosti 25,50 EUR/CZK | FXstreet.cz. [online] Available at: <https://www.fxstreet.cz/zpravodajstvi-121197.html> [Accessed 14 November 2021].

GURTLER, M., 2021. Investiční bankovnictví, Komerční banka a.s.. [online] Trading.kb.cz. Available at: <https://trading.kb.cz/CommentsAnalysis/Detail/d3a3ea78_cnb_zvysi_urokove_sazby_o_nestan dardnich_50_bb> [Accessed 14 November 2021].

HAVRANEK, T. AND RUSNAK, M., 2012. Transmission lags of monetary policy: A meta-analysis. 
HODRICK, R.J., 1978. „An Empirical Analysis of the Monetary Approach to the Determination of the Exchange Rate ". The economics of exchange rates, pp.97-116.

HROMADA, E., KRULICKY, T. Investing in Real Estate in the Czech Republic and Analyzing the Dependence of Profitability and Technical and Socio-Economic Factors. Sustainability. 2021; 13(18):10273. https://doi.org/10.3390/su131810273

HUDSON, J., FIELDING, S. AND RAMSAY, C.R., 2019. Methodology and reporting characteristics of studies using interrupted time series design in healthcare. BMC medical research methodology, 19(1), pp.1-7.

ISLAM, M., HOSSAIN, E., RAHMAN, A., HOSSAIN, M.S. AND ANDERSSON, K., 2020. A review on recent advancements in forex currency prediction. Algorithms, 13(8), p.186.

KADEŘÁBKOVÁ, B., JAŠOVÁ, E. 2020: COMPARATION OF THE ECONOMIC CYCLE ON LABOUR MARKET IN THE CONSTRUCTION INDUSTRY AND IN THE NATIONAL ECONOMY OF THE CZECHIA. Civil Engineering Journal Stavebni obzor,3/2020, DOI 10.14311/CEJ.2020.03.0024

KATSIMEROU, C., 2021. There's more to experimentation than A/B. [online] Medium. Available at: <https://booking.ai/theres-more-to-experimentation-than-a-b-223fba846876> [Accessed 14 November 2021].

KONDRATENKO, V.V. AND KUPERIN, Y.A., 2003. Using recurrent neural networks to forecasting of forex. arXiv preprint cond-mat/0304469.

KRAL, P., 2021. Nehraje se o nic menšího, než je důvěra lidí v cenovou stabilitu - Česká národní banka. [online] Cnb.cz. Available at: <https://www.cnb.cz/cs/o_cnb/cnblog/Nehraje-se-o-nic-mensihonez-je-duvera-lidi-v-cenovou-tabilitu/?fbclid=IwAR0sCnY5IxYK_nkO82bhGdAfBnd_R6181Wfa26oOG1wJc5aDPbHoOqPQhM> [Accessed 14 November 2021].

MOENJAK, T., 2014. Central banking: theory and practice in sustaining monetary and financial stability. John Wiley \& Sons.

OANCEA, B., AND ŞTEFAN C.C. "Time series forecasting using neural networks." arXiv preprint arXiv:1401.1333 (2014).

OGUTU, L., 2020. Improving Accuracy of Counterfactual Estimation for Sales Forecasting Using an Ensemble of ARMA, ANN and BSTS Models.

PINILLA, J., NEGRÍN, M., GONZÁLEZ-LÓPEZ-VALCÁRCEL, B. AND VÁZQUEZ-POLO, F.J., 2018. Using a Bayesian structural time-series model to infer the causal impact on cigarette sales of partial and total bans on public smoking. Jahrbücher für Nationalökonomie und Statistik, 238(5), pp.423-439.

PLÜMPER, T. AND TROEGER, V.E., 2006. Monetary policy autonomy in European non-euro countries, 1980-2005. European Union Politics, 7(2), pp.213-234.

POYSER, O., 2019. Exploring the dynamics of Bitcoin's price: a Bayesian structural time series approach. Eurasian Economic Review, 9(1), pp.29-60.

ROSSI, B., 2013. Exchange rate predictability. Journal of economic literature, 51(4), pp.1063-1119.

SCOTT, S.L. AND VARIAN, H.R., 2015. 4. Bayesian Variable Selection for Nowcasting Economic Time Series (pp. 119-136). University of Chicago Press..

SEZER, O., MEHMET U.G., AND OZBAYOGLU A.M. "Financial time series forecasting with deep learning: A systematic literature review: 2005-2019." Applied Soft Computing 90 (2020): 106181.

TAKYI, P.O. AND BENTUM-ENNIN, I., 2021. The impact of COVID-19 on stock market performance in Africa: A Bayesian structural time series approach. Journal of Economics and Business, 115, p.105968. 